\title{
Formulation and Evaluation of Some Novel Breakfast Blends Made from Cereals and Legumes
}

\author{
Rehab, A. Mostafa ${ }^{1}$, Azza, E. M. Abd-El Haleem² \&Salwa, S. Gabal ${ }^{1}$ \\ ${ }^{1}$ Food Technology Research Institute. Agricultural Research Center ARC, Giza, Egypt. \\ ${ }^{2}$ Food Science and Technology Dept., Fac. of Agric., Alexandria Univ., 21545, EL-Shatby, Alexandria, \\ Egypt
}

Received: 6 November, 2017

Revised: 14 December, 2017

Accepted: 24 December, 2017

\begin{abstract}
Four samples of breakfast cereal-legume blends were generated by mixing the flours (wheat, maize, rice, lentil, bean, chickpeas and kidney beans) with almond, bran and dates, in addition to others additives such as powdered skimmed milk, honey, baking powder, baking soda and flavoured (vanillin + cinnamon). Gelatinization of the grains and legumes starch was produced by roasting to obtain ready to eat breakfast cereal products. They were subjected to proximate, sensory, minerals, vitamins, anti-nutrients and acrylamide analysis. The products obtained were also served dry with warm milk to 10 panelists along with control sample to be evaluated for colour, taste, odour, texture and overall acceptability using a 9 point hedonic scale. The results showed the following ranges: Proximate composition (\%): Moisture (12.95- 16.67), protein (7.71-13.06), crude ether extract (4.48-7.99), ash(2.30-2.52), carbohydrate (62.84-71.80),crude fiber (3.13-3.98) Energy ranged from 358.36 to $375.71 \mathrm{kcal}$. Minerals analysis reported the following ranges (mg/100g): $\mathrm{Fe}$ (3.55-4.93), $\mathrm{Zn}$ (8.60-9.38), $\mathrm{Mn}$ (0.85-1.63), $\mathrm{Ca}(429.55-641.19), \mathrm{Mg}(91.33-94.80)$, $\mathrm{Na}(24.66-39.17)$ and $\mathrm{K}$ (4.94-5.52). Vitamins analysis revealed the following ranges (mg/100g): Ascorbic acid (5.867.68), $\mathrm{B}_{2}(1.46-1.68), \mathrm{B}_{3}(3.94-4.64), \mathrm{B}_{9}(0.487-0.585)$, $\beta$-carotene (3.91-6.16), $\mathrm{E}(4.24-5.63)$. The anti-nutritional factors showed the ranges: Trypsin inhibitor (13.61TIU/mg-24.71TIU/mg), phytic acid $(129.10 \mathrm{mg} / 100 \mathrm{~g}-220.77 \mathrm{mg} / 100 \mathrm{~g})$, haemaggluttinating activities (128.59U/100g-284.50U/100g), alkaloids $(64.69 \mathrm{mg} / 100 \mathrm{~g}-183.33 \mathrm{mg} / 100 \mathrm{~g})$, and oxalic acid $(19.77 \mathrm{mg} / 100 \mathrm{~g}-88.93 \mathrm{mg} / 100 \mathrm{~g})$. Protein digestibility exhibited values ranged from $83.20 \%$ to $90.11 \%$. The acrylamide content of the four blends ranged from $281.18 \mu \mathrm{g} / \mathrm{kg}$ to $363.00 \mu \mathrm{g} / \mathrm{kg}$.
\end{abstract}

Key words:-Breakfast cereal-legume blends, acrylamide, anti-nutritional factors.

\section{INTRODUCTION}

The benefit of human health was related to the consumption of wholegrain cereal in breakfast. Due to all the cereals contained bran, germ and endosperm, it is found to be reliable source of protein, fibers, vitamins and minerals. Consumption of breakfast cereals make from whole grains (wheat and oats) can reduce coronary heart disease risk (Woods \& Walker, 2007).

The annual world production from cereal is more than 2.5 billion tons. All whole cereals are starchy foods and also considered as good source of energy, vitamins B, dietary fiber and protein. On the other hand, all cereals lack in the essential amino acids which are necessary for children development (Zhai et al.,2015). Fortunately, legumes are good source of proteins and allow consumers to choice healthier types of ready to eat foods. (Gupta \&Sehgal, 1991).
The manufacturing technique of breakfast cereal products was a multi-step, firstly cold water and/or heat are added in conditioning step, this step to adjust the structure of grain physically and give rise additional functions. Manufacturers treat using heat to carry out a desirable flavour "nutty flavour" and put on diverse levels of moisture for grain's that immediately will be used for hot cereal or for flour. Grains are milled for flour or steamed and rolled into flakes. Finally, grains become able to be identified from the consumers as hot cereals (Berkenkamp et al., 2015). Supplementation with a very high protein crop suitable as weaning foods is necessary to solve the starvation and obesity problems in the World. This supplementation was as formulation of cereallegume blends for children of weaning age (Wakil \&Kazeem, 2012). These supplements as food formulations were known as functional foods which are concerning the food manufacturers. A food can be made functional by applying any technological 
means to take off or change in the components, as efficiently as, to get better its bioavailability to receive functional effects (Niva, 2007).

The aim of the present study is to formulate and evaluate some novel breakfast blends made from cereals and legumes.

\section{MATERIALS AND METHODS}

\section{Materials}

The seeds of wheat, corn, rice, lentil, bean, chickpeas and kidney bean were obtained from the local market, Alexandria, Egypt. The clean seeds were kept at room temperature in air tight containers.

\section{Methods}

\section{Processing procedure}

Soaking: The seeds were steeped in double amount of water at ambient temperature for $12 \mathrm{hr}$ and drained.

Roasting: The drained seeds were roasted in an oven at $280^{\circ} \mathrm{C}$ for $5 \mathrm{~min}$.

The roasted seeds were ground in electric mill (mesh size $0.5 \mathrm{~mm}$ ) separately. The flours thus obtained and powder were thoroughly blended with the same ratios to obtain the composite seed flour.

Breakfast Cereals-Legume Blends: The prepared recipes are shown in Table (1).

Processing: According to Fast (1990), the breakfast cereal-legume blends were prepared as shown in Fig (1).

\section{Sensory evaluation}

The four samples formulated in the present study were served to 10 trained panelists from the students of the University of Alexandria. The pan- elists were asked to judge the samples on 9-point Hedonic scale. The samples and the control were served dry with warm milk and evaluated corresponding colour, taste, odour, texture and overall acceptability (Meilgaard et al., 1991).

\section{Nutrient analysis}

\section{Gross chemical composition}

The breakfast cereals were analyzed for moisture,crude protein $(\mathrm{N} \times 6.25)$, crude ether extract,ash and carbohydrate (by difference) according to the AOAC (2007). Crude fibers were determined by the AOAC (2007).

Caloric values were calculated from the sum of the percentages of crude protein and total carbohydrates multiplied by a factor of $4\left(\mathrm{Kcal}_{\mathrm{g}} \mathrm{g}^{-1}\right)$ plus the crude fat content multiplied by $9\left(\mathrm{Kcal}_{\mathrm{g}} \mathrm{g}^{-1}\right)$ according to Zambronaet al. (2004).

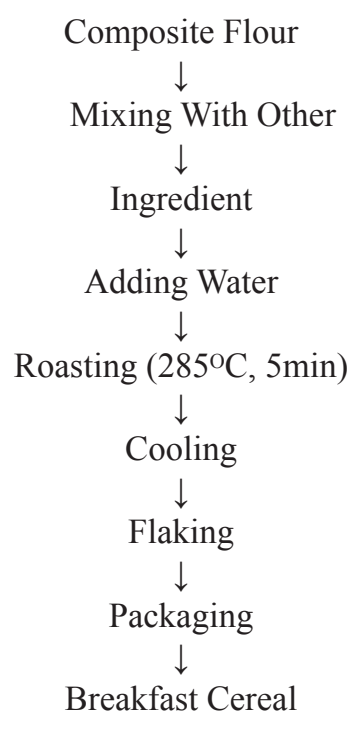

Fig 1: Flow diagram showing the procedure to prepare breakfast cereal- legume blends

Table 1: Ingredients combination for breakfast cereals-legume blends

\begin{tabular}{|c|c|c|c|c|}
\hline Ingredients (\%) & Control & **Dates (Ajwa) & $* *$ Nuts (Almond) & Wheat bran \\
\hline Composite flour* & 90 & 70 & 70 & 70 \\
\hline Other additive & 0 & 20 & 20 & 20 \\
\hline Powdered skimmed milk & 5.5 & 5.5 & 5.5 & 5.5 \\
\hline Honey & 3 & 3 & 3 & 3 \\
\hline Baking powder & 0.5 & 0.5 & 0.5 & 0.5 \\
\hline Baking soda & 0.5 & 0.5 & 0.5 & 0.5 \\
\hline Flavoured (vanillin + cinnamon) & 0.5 & 0.5 & 0.5 & 0.5 \\
\hline
\end{tabular}

*Composite flour is mixed in equal ratios of wheat, maize, rice, lentil, bean, chickpeas and kidneybean seeds **Addition in slurry form. 


\section{Minerals}

Minerals (Iron, manganese, calcium, magnesium, sodium, potassium and zinc) contents were determined by dry ashing according to the AOAC (2007) using an Atomic Absorption Spectrophotometer ( Model 2380,USA).

\section{Vitamin contents}

The vitamins (ascorbic acid, riboflavin, niacin, folic acid, ß-carotene and tocopherol) contents were dee termined by Reversed-phase HPLC using acetonitrile (polar solvent), dichloromethane(lower polarity) and methanol (hydrogen bonding capacity)solvents as a typical NARP mobile phase. The vitamins were separated on the Acclaim ${ }^{\circledR}$ Polar Advantage (PA) II column with a single injection using an aqueous-to non-aqueous mobile phase gradient. The HPLC columns-Acclaim PA, PA2, and C18 - were used for the separations with an aqueous mobile phase (phosphate buffer- $\mathrm{CH}_{3} \mathrm{CN}$ ) for water-soluble vitamins and a non-aqueous mobile phase $\left(\mathrm{CH}_{3} \mathrm{OH}-\mathrm{CH}_{3} \mathrm{CN}\right.$-methyl tert-butyl ether) for fat-soluble vitamins. Detection wavelength-switching mode was applied for sensitivity optimization (Moreno \&Salvado, 2000).

\section{Analysis of antinutritional factors}

Trypsin inhibitor was extracted and determined using Lin \& Chen (1989 ) method. Phytic acid was determined according to Wheeler \& Ferrel (1971).

Haemagglutinin determination was by spectrophotometric method as described by Onwuka (2005).Alkaloids and oxalate were analyzed according to the AOAC (2007).

\section{Protein digestibility}

Protein digestibility was determined using enzymatic hydrolysis (pepsin and pancreatin), then the nitrogen contents were analyzed by the microKjeldahl method. The protein digestibility of samples were calculated by subtracting undigested protein from crude protein of the blends (Prakash \& Prakash, 1999).

\section{Acrylamide (AA) analysis}

One hundred $g$ of each sample were finely pulverized, homogenized and dehydrated at $103^{\circ} \mathrm{C}$ for 4 hour, prior to sampling. Solid samples $2 \mathrm{~g}$ each were accurately weighed into centrifuge tubes. A volume of $10 \mu \mathrm{l}$ of the internal standard solution, Acrylamide at $100 \mu \mathrm{g} / \mathrm{mL}$, was added to one centrifuge tube for recovery study. Eight $\mathrm{ml}$ of water was used to extract acrylamide from blends and centrifuged for $15 \mathrm{~min}$ at $3100 \mathrm{x} \mathrm{g}$. The aqueous phase was collected and the extraction process was repeated twice. The supernatant was mixed with 1 $\mathrm{ml}$ of a $0.355 \mathrm{~mol} / 1$ potassium hexacyanoferrate (II) trihydrate solution (Carrez I) and $1 \mathrm{~mL}$ of a 1.04 $\mathrm{mol} / \mathrm{l}$ zinc sulphateheptahydrate solution (Carrez II) and refrigerated for $30 \mathrm{~min}$, then centrifuged. The extract were concentrated to $1 \mathrm{~mL}$ by evaporation under vacuum at $45^{\circ} \mathrm{C}$ kept in dark glass vials at $4^{\circ} \mathrm{C}$ until injection. The acrylamide determination was carried out using HPLC-UV instrument. An isocratic elution was performed at a flow rate of $0.5 \mathrm{ml} / \mathrm{min}$, the mobile phase consisted of water/acetonitrile $96: 4(\mathrm{v} / \mathrm{v})$, the retention time of AA was $10.1 \mathrm{~min}$, and the total run time was $35 \mathrm{~min}$. AA was detected by PAD detector ( 200.5 and 210 $\mathrm{nm}$ ), at room temperature.. Under these chromatographic conditions, AA and the food components in the samples were all separated and eluted. The AA content is resulting from an average of three measurements and the relative standard deviation of each sample was below 10\% (Kapeiet al.,2015).

\section{Statistical Analysis}

The analysis of variance of the results was performed according to Steel \&Torrie (1980). Statistical analysis was carried out by ANOVA and LSD procedure. The analysis was computed using the SpSS11.5 program.

\section{RESULTS AND DISCUSSION}

\section{Sensory properties}

The data presented in Table (2) revealed that all formulated samples were significantly $(\mathrm{P} \leq 0.05)$ accepted for all the sensory properties. The best blend was that contained dates slurry, while blend containing nuts exhibited superior significantly $(\mathrm{P} \leq 0.05)$ colour and overall acceptability. On the other hand, blend containing wheat bran was significantly $(\mathrm{P} \leq$ $0.05)$ superior in taste and odour. However the texture of both blends had the same record. Finally, the control sample recorded significantly $(\mathrm{P} \leq 0.05)$ lower acceptability comparing with the other samples.

\section{Chemical composition}

Chemical composition of breakfast cereal legume blends are shown in Table (3). The moisture content ranged from $12.95 \%$ in wheat bran blend to $16.67 \%$ in dates blend. The samples generally had low moisture content which implied that 
Table 2: Sensory properties of the breakfast cereal-legume blends

\begin{tabular}{lcccc}
\hline \multicolumn{1}{c}{ Properties } & \multicolumn{4}{c}{ Blends } \\
\cline { 2 - 5 } & Control & Dates & Nuts & Wheat bran \\
\hline Colour & $7.40 \pm 1.03^{\mathrm{b}}$ & $8.30 \pm 0.64^{\mathrm{a}}$ & $7.70 \pm 0.69^{\mathrm{b}}$ & $7.60 \pm 1.25^{\mathrm{b}}$ \\
Taste & $6.70 \pm 1.56^{\mathrm{a}}$ & $7.00 \pm 1.55^{\mathrm{a}}$ & $6.60 \pm 2.17^{\mathrm{a}}$ & $6.80 \pm 2.71^{\mathrm{a}}$ \\
Odour & $7.00 \pm 1.26^{\mathrm{a}}$ & $7.30 \pm 1.10^{\mathrm{a}}$ & $6.90 \pm 1.62^{\mathrm{a}}$ & $7.20 \pm 1.89^{\mathrm{a}}$ \\
Texture & $6.90 \pm 1.45^{\mathrm{a}}$ & $7.20 \pm 1.21^{\mathrm{a}}$ & $7.00 \pm 1.51^{\mathrm{a}}$ & $7.00 \pm 1.92^{\mathrm{a}}$ \\
Overall acceptability & $6.80 \pm 1.10^{\mathrm{b}}$ & $7.40 \pm 0.92^{\mathrm{b}}$ & $7.70 \pm 0.92^{\mathrm{a}}$ & $7.30 \pm 1.37^{\mathrm{b}}$ \\
\hline
\end{tabular}

Values followed by the same letter in a row are not significantly different at $\mathrm{P} \leq 0.05$.

the samples could have an extended shelf life in their raw form, since the moisture content of a food affects its stability and overall quality. The crude protein content ranged from $7.71 \%$ to $13.06 \%$ and the significantly highest content was for the nuts blend while the significantly lowest content was for the control one. The protein content of the samples was higher than that of a popular breakfast cereal in Nigeria, which has been reported to contain $10.92 \%$ crude protein. Samuel \& Otegbayo (2006) reported that ogi (a popular breakfast cereal in Nigeria) fortified with $14.16 \%$ protein from soya bean plays a part in the organoleptic properties of the sample in addition to being a source of amino acids.

The crude ether extract content ranged from $4.48 \%$ in the control blend to $7.99 \%$ in nuts one. The range of crude fat detected was within the range of 13.37 to $21.50 \%$ as reported by Okafor\& Usman (2013).

The ash content ranged from $2.30 \%$ to $2.52 \%$. The significantly $(\mathrm{P} \leq 0.05)$ highest ash content was found in the nuts blend. These value are comparable to the value of 1.97 to 2.05 reported by Okafor \& Usman (2013).
The carbohydrate content ranged from $62.84 \%$ in nuts blend to $71.80 \%$ in the control. The higher carbohydrate values recorded by other researchers may be attributed to the high content of the cereals and legumes used as the principal ingredients in the formulations (Kanu et al., 2009).

The crude fiber content ranged from $3.19 \%$ to $3.98 \%$. The significantly $(\mathrm{P} \leq 0.05)$ highest content was traced for bran blend. McKevith (2004) found that dietary fibers are important for the removal of waste from the body thereby preventing constipation and many health disorders.

The energy values were the lowest for the control blend and the highest for dates blend. Kent (1983) obtained similar caloric values for treated ready-to-eat breakfast cereal foods of energy value between 314.0 - $420.0 \mathrm{KcaV} 100 \mathrm{~g}$. The high energy content is advantageous for product formulation like breakfast cereals.

\section{Mineral contents:}

Table (4) shows the mineral contents of the different blends. These values are presented along with the corresponding values obtained from the

Table 3: Chemical composition of the breakfast cereal -legume blends (on dry weight basis)

\begin{tabular}{lllll}
\hline \multirow{2}{*}{ Components } & \multicolumn{4}{c}{ Blends } \\
\cline { 2 - 5 } \multicolumn{1}{c}{ Control } & \multicolumn{1}{c}{ Dates } & Nuts & Wheat bran \\
\hline Moisture & $13.52 \pm 0.22 \mathrm{~b}$ & $16.67 \pm 0.97 \mathrm{a}$ & $13.63 \pm 0.21 \mathrm{~b}$ & $12.95 \pm 0.13 \mathrm{c}$ \\
Crude protein $(\mathrm{N} \times 6.25)$ & $7.71 \pm 0.07 \mathrm{~d}$ & $8.73 \pm 0.07 \mathrm{c}$ & $13.06 \pm 0.16 \mathrm{a}$ & $9.67 \pm 0.55 \mathrm{~b}$ \\
Crude ether extract & $4.48 \pm 0.21 \mathrm{~d}$ & $5.08 \pm 0.18 \mathrm{c}$ & $7.99 \pm 0.11 \mathrm{a}$ & $7.44 \pm 0.07 \mathrm{~b}$ \\
Ash & $2.50 \pm 0.40 \mathrm{a}$ & $2.30 \pm 0.17 \mathrm{a}$ & $2.48 \pm 0.39 \mathrm{a}$ & $2.52 \pm 0.39 \mathrm{a}$ \\
Carbohydrate* & $71.80 \pm 0.42 \mathrm{a}$ & $67.22 \pm 0.21 \mathrm{ba}$ & $62.84 \pm 0.60 \mathrm{c}$ & $67.42 \pm 0.25 \mathrm{ba}$ \\
Crude fiber & $3.19 \pm 0.75 \mathrm{a}$ & $3.93 \pm 0.04 \mathrm{a}$ & $3.73 \pm 0.05 \mathrm{a}$ & $3.98 \pm 0.86 \mathrm{a}$ \\
Energy value $($ Kcal $\backslash 100 \mathrm{~g})$ & $358.36 \pm 16.92 \mathrm{a}$ & $375.71 \pm 16.81 \mathrm{a}$ & $375.51 \pm 2.9 \mathrm{a}$ & $375.32 \pm 1.78 \mathrm{a}$ \\
\hline
\end{tabular}

Calculated by difference

Values followed by the same letter in a row are not significantly different at $\mathrm{P} \leq 0.05$. 
Table 4: Mineral contents of the breakfast cereal-legume blends (mg/100g) on dry weight basis

\begin{tabular}{|c|c|c|c|c|c|}
\hline \multirow{2}{*}{ Elements } & \multicolumn{4}{|l|}{ Blends } & \multirow{2}{*}{ USRAD* } \\
\hline & Control & Dates & Nuts & Wheat bran & \\
\hline $\mathrm{Fe}$ & 4.93 & 4.73 & 3.55 & 4.01 & $10-15$ \\
\hline $\mathrm{Zn}$ & 8.71 & 9.38 & 8.60 & 8.73 & $12-15$ \\
\hline $\mathrm{Mn}$ & 0.89 & 0.85 & 1.12 & 1.63 & $2-5$ \\
\hline $\mathrm{Ca}$ & 641.19 & 532.82 & 429.55 & 457.78 & 1000 \\
\hline $\mathrm{Mg}$ & 91.93 & 94.80 & 93.20 & 91.33 & $280-350$ \\
\hline $\mathrm{Na}$ & 24.86 & 24.66 & 29.35 & 39.17 & 500 \\
\hline $\mathrm{K}$ & 5.53 & 5.21 & 5.40 & 4.94 & 3.5 \\
\hline
\end{tabular}

*USRAD United States Recommended Dietary Allowance day (mg/kg body weight/day).

control sample. The iron and calcium contents of the blends ranged from 3.55 to $4.93 \mathrm{mg} / 100 \mathrm{~g}$ and 429.55 to $641.19 \mathrm{mg} / 100 \mathrm{~g}$, respectively. The highest value was found in the control blend and the lowest was found in the nuts blend. The values of iron contents are lower than the values recommended by United States Recommended Dietary Allowance (USRDA) being $10-15 \mathrm{mg} / 100 \mathrm{~g}$. The results presented here exhibited that each $100 \mathrm{~g}$ of the formulated samples can provide about 35.50 $32.87 \%$ of the USRDA requirement of iron. On the other hand, the values of calcium contents represent about $42.96 \%$ to $64.12 \%$ of USRDA requirements $(1000 \mathrm{mg} / 100 \mathrm{~g})$.

Manganese and sodium contents ranged from $0.85 \mathrm{mg} / 100 \mathrm{~g}$ to $1.63 \mathrm{mg} / 100 \mathrm{~g}$ and $24.66 \mathrm{mg} / 100 \mathrm{~g}$ to $39.17 \mathrm{mg} / 100 \mathrm{~g}$, respectively. The highest value was found in wheat bran blend while the lowest valuein dates blend. The manganese contents in blends represented $32.60 \%$ to $42.50 \%$ of USRDA requirement $(2-5 \mathrm{mg} / 100 \mathrm{~g})$. Moreover, the sodium values were far less than the required value recorded by the USRDA $(500 \mathrm{mg} / 100 \mathrm{~g})$.

Zinc content ranged from $8.60 \mathrm{mg} / 100 \mathrm{~g}$ to $9.38 \mathrm{mg} / 100 \mathrm{~g}$, magnesium contents ranged from 91.33 to $94.80 \mathrm{mg} / 100 \mathrm{~g}$ and potassium contents in the formulated blends ranged from $4.94 \mathrm{mg} / 100 \mathrm{~g}$ to $5.53 \mathrm{mg} / 100 \mathrm{~g}$. The values of these three elements (zinc, magnesium and potassium) showed trace different in the four formulated blends. The values of zinc were lower than USRDA range $(12-15 \mathrm{mg} / 100 \mathrm{~g})$, consequently, each $100 \mathrm{~g}$ of the formulated samples can provide about $62.53 \%$ to $71.67 \%$ of the USRDA requirement of zinc. Also, the magnesium contents in blends represented
$27.08 \%$ to $32.62 \%$ of USRDA requirement $(280$ - $350 \mathrm{mg} / 100 \mathrm{~g}$ ). Finally, the potassium limits in the blends were more than the USRDA requirements $(3.5 \mathrm{mg} / 100 \mathrm{~g})$ being higher by about 62.29 to 70.85 folds. In accordance with the results obtained in the present study, higher potassium values $(70.19 \pm 6.82 \mathrm{mg} / \mathrm{kg})$ were recorded for fortified breakfast cereals (Usman, 2012).

\section{Vitamin contents}

Table (5) shows the water and fat soluble vitamin contents of the breakfast cereal -legume blends. The results revealed that the products contained high values of ascorbic acid (5.68 $7.68 \mathrm{mg} / 100 \mathrm{~g}$ ), ß-carotene (3.91-6.16mg/100g), tocopherol $(4.24-5.63 \mathrm{mg} / 100 \mathrm{~g})$ and niacin $(3.94$ $-4.64 \mathrm{mg} / 100 \mathrm{~g})$ contents and low values of riboflavin $(1.46-1.86 \mathrm{mg} / 100 \mathrm{~g})$ and folic acid $(0.487$ $-0.585 \mathrm{mg} / 100 \mathrm{~g})$ contents. Generally, the results showed that vitamins content in breakfast cereal can be improved through supplementation with blends of cereal and legume flour beside almond, dates or wheat bran. In the present study, the wheat bran breakfast cereal-legume blend was the lowest in ascorbic acid, riboflavin, niacin, folic acid and $\beta$-carotene contents. On the other hand, the results showed that the nuts blend was the highest in riboflavin, niacin and folic acid and tocopherol contents. Meanwhile, the control blend was the lowest in the tocopherol content and the dates blend was the highest in $\beta$-carotene content.

The whole-grain wheat breakfast cereal showed a lower total vitamin E content (796.90 $\pm 33.72 \mu \mathrm{g} / 100 \mathrm{~g}$ ) than in whole grain sorghum breakfast cereal $(3727.50 \pm 352.0 \mu \mathrm{g} / 100 \mathrm{~g})$ as found by Anunciação, et al. (2017). Banu, et al. (2012) 
Table 5: Water and fat soluble vitamin contents of the breakfast cereal-legume blends (mg/100g) on dry weight basis

\begin{tabular}{|c|c|c|c|c|}
\hline \multirow{2}{*}{ Vitamins } & \multicolumn{4}{|c|}{ Blends } \\
\hline & Control & Dates & Nuts & Wheat bran \\
\hline Ascorbic acid (C) & 6.20 & 7.68 & 6.06 & 5.68 \\
\hline Riboflavin $\left(\mathrm{B}_{2}\right)$ & 1.50 & 1.64 & 1.68 & 1.46 \\
\hline Niacin $\left(B_{3}\right)$ & 4.24 & 4.55 & 4.64 & 3.94 \\
\hline Folic acid $\left(\mathrm{B}_{9}\right)$ & 0.504 & 0.583 & 0.585 & 0.487 \\
\hline ß-carotene & 4.80 & 6.16 & 5.15 & 3.91 \\
\hline Tocopherol (E) & 4.24 & 5.15 & 5.63 & 4.29 \\
\hline
\end{tabular}

found that riboflavin content ranged from 8.7 to $21.6 \mu \mathrm{g} / 100 \mathrm{gm}$ in mixture made from different cereals, legumes, millets, nuts. Meanwhile, Usman, (2012) showed that the B2 vitamin content of the breakfast cereal products ranged from $0.32 \pm 0.10$ to $0.43 \pm 0.02 \mathrm{mg} / 100 \mathrm{~g}$, and were lower than the recorded values for the control $(1.08 \mathrm{mg} / 100 \mathrm{~g})$ and the US RDA requirement $(1.70 \mathrm{mg} / \mathrm{kg})$, while vitamin $\mathrm{C}$ content of the formulated samples ranged from $1.70+0.02$ to $2.65+0.02 \mathrm{mg} / 100 \mathrm{~g}$. These values are lower than the US RDA for men, women and children $(30-60 \mathrm{mg} / \mathrm{kg})$.

\section{Anti-nutritional factors}

Anti-nutritional factors contents of the blends are presented in Table (6). The mean trypsin inhibitors activity values ranged between 13.61 to $24.71 \mathrm{TIU} / \mathrm{mg}$. The significantly highest value was in wheat bran blend and the significantly lowest value in the dates one. Ojo, et al.(2014) showed that elimination or inactivation of trypsin inhibitors by processing is necessary to improve nutritional quality and effectively utilize its full potential as human food. So that process like soaking and roasting in preparation of legume- cereal breakfast products were effective to reduce trypsin inhibitor in products as compared with its original content in legumes.

Phytic acid level of the blends ranged between 129.10 to $220.77 \mathrm{mg} / 100 \mathrm{~g}$ where the wheat bran blend had significantly the highest level whereas, the dates blend had significantly the lowest level. On the other hand, nuts blend and the control one had $176.24 \mathrm{mg} / 100 \mathrm{~g}$ and $210.50 \mathrm{mg} / 100 \mathrm{~g}$, respectively. Onyango et al. (2012) showed that the phytate content of instant control (untreated grains) breakfast cereals from optimized flours of pear millet, red and white sorghum ranged from 183.50 $\mathrm{mg} / 100 \mathrm{~g}$ to $185.32 \mathrm{mg} / 100 \mathrm{~g}$.
Haemagglutinin (lectins) activities in legumecereal breakfast blends ranged from 128.59 to $284.50 \mathrm{U} / 100 \mathrm{~g}$. At the same manner, the wheat bran blend had the significantly highest level and the dates blend had the significantly lowest level. On the other hand, nuts blend and the control one had 167.06 and $240.65 \mathrm{U} / 100 \mathrm{~g}$, respectively. Preprocessing treatments (soaking, cooking and roasting) of cereals and legumes removed the toxicity effect of lectins (Jain et al., 2009).

The alkaloids of legume-cereal breakfast blends ranged from 64.69 to $183.33 \mathrm{mg} / 100 \mathrm{~g}$, where the significantly highest contain were recorded in dates blend while the significantly lowest was found in the control. Moreover, nuts and wheat bran blends recorded 82.93 and $116.66 \mathrm{mg} / 100 \mathrm{~g}$, respectively. The alkaloid content of the seeds flours examined (Pear seeds and Watermelon seeds flours) were $10.14 \%$ and $15.34 \%$, respectively (Olorode Omobolanueet al., 2014).

Oxalate content of the blends under investigation ranged from $19.77 \mathrm{mg} / 100 \mathrm{~g}$ to $88.93 \mathrm{mg} / 100 \mathrm{~g}$. Oxalate content of dates blend was significantly the lowest while the wheat bran blend had the significantly highest content. Usman et al. (2015) reported that the oxalate content of breakfast cereal blends made from rice, soybean and defatted coconut flours ranged from $0.077 \mathrm{mg} / \mathrm{g}$ to $1.47 \mathrm{mg} / \mathrm{g}$. The protein digestibility of these blends ranged from $83.20 \%$ to $90.11 \%$. The significantly lowest percent was in wheat bran blend while the significantly highest percent was in dates blend. Onyango et al. (2012) found that the percent of protein digestibility were $87.67 \%, 91.14 \%$ and $92.90 \%$ in developed (alkali treatment, malting, fermentation and with protein complementation with pigeon peas) red sorghum, and white sorghum breakfast cereal products, respectively. 
Table 6: Anti-nutritional factors and Protein digestibility of the breakfast cereal-legume blends on dry weight basis.

\begin{tabular}{lllll}
\hline \multirow{2}{*}{ Factors } & \multicolumn{4}{l}{ Blends } \\
\cline { 2 - 5 } & Control & Dates & Nuts & Wheat bran \\
\hline Trypsin inhibitor (TIU/ mg) & $20.31 \pm 0.76 \mathrm{~b}$ & $13.61 \pm 1.07 \mathrm{~d}$ & $17.18 \pm 0.90 \mathrm{c}$ & $24.71 \pm 1.36 \mathrm{a}$ \\
Phytic acid (mg/ 100g) & $210.50 \pm 3.47 \mathrm{~b}$ & $129.10 \pm 3.12 \mathrm{~d}$ & $176.24 \pm 1.83 \mathrm{c}$ & $220.77 \pm 3.05 \mathrm{a}$ \\
Haemagglutinin Activities (U/ 100g) & $240.65 \pm 2.33 \mathrm{~b}$ & $128.59 \pm 3.05 \mathrm{~d}$ & $167.06 \pm 3.82 \mathrm{c}$ & $284.50 \pm 2.37 \mathrm{a}$ \\
Alkaloids (mg/100g) & $64.69 \pm 1.74 \mathrm{~d}$ & $183.33 \pm 2.42 \mathrm{a}$ & $82.93 \pm 2.05 \mathrm{c}$ & $116.66 \pm 1.65 \mathrm{~b}$ \\
Oxalates (mg/ 100g) & $30.82 \pm 0.85 \mathrm{c}$ & $19.77 \pm 1.15 \mathrm{~d}$ & $53.78 \pm 1.34 \mathrm{~b}$ & $88.93 \pm 1.65 \mathrm{a}$ \\
Protein digestibility (\%) & $88.08 \pm 0.22 \mathrm{~b}$ & $90.11 \pm 0.28 \mathrm{a}$ & $86.19 \pm 0.46 \mathrm{c}$ & $83.20 \pm 0.36 \mathrm{~d}$ \\
\hline
\end{tabular}

Values followed by the same letter in a row are not significantly different at $\mathrm{P} \leq 0.05$.

\section{Acrylamide analysis (AA)}

As shown in Fig. (2), the acrylamide contents in the breakfast cereal blends formulated in the present study varied from $281.18 \mu \mathrm{g} / \mathrm{kg}$ to $363.00 \mu \mathrm{g} /$ $\mathrm{kg}$. The significantly $(\mathrm{P} \leq 0.05)$ highest level was in dates blend and the lowest level was in the control one, while the intermediate levels were in both of the bran and the nuts blends. Acrylamide content was determined in maize, wheat, rice, sorghum pearl millet, soybean and chickpea which used in preparing cereal and legume based food products. The highest value was in maize $(2195.31 \mu \mathrm{g} / \mathrm{kg})$ and the lowest value was in wheat $(161.12 \mu \mathrm{g} / \mathrm{kg})$ .Meanwhile the intermediate values were in the other cereals and legumes (Galaniet al., 2017).

\section{CONCLUSION}

The present study has shown that nutritious breakfast cereal can be produced from blends of local seven seeds such as wheat, maize, rice, lentil, bean, chickpeas and kidney beans. The results obtained show that all formulated samples were found to be satisfied acceptable, high in protein contents ( $7.71 \%$ to $13.06 \%$ ), ether extract (4.48\% to $7.99 \%$ ) and ash content (2.30\% to $2.52 \%)$. Moreover, these blends were high in minerals such as calcium and magnesium and vitamin B. Therefore, these breakfast cereal- legume blends products can be used by both adults and children alike because they are considered to be healthier types of ready to eat foods.

\section{REFERENCES}

Anunciação, P.C., Cardoso, L. M., Gomes, J. V. P., Lucia, C. M. D., Carvalho, C. W. P., Galdeano, M. C., Queiroz, V. A. V., Alfenas, R. G., Martino, H. S. D. \&Pinheiro-Sant'Ana, H. M. 2017.Comparing sorghum and wheat whole grain breakfast cereals: Sensorial acceptance and bioactive compound content. Food Chemistry, 221: 984-989.

AOAC. 2007. Official Methods of Analysis of the A.O.A.C. International $18^{\text {th }}$ Ed. Gaithersburg, Maryland, USA.



Fig. 2 Acrylamide contents of breakfast cereal- legume blends ( $\mu \mathrm{g} / \mathrm{kg}$ sample) 
Banu, H., Itagi, N. \& Singh, V. 2012.Preparation, nutritional composition, functional properties and antioxidant activities of multigrain composite mixes. Journal of Food Science and Technology, 49: 74-81.

Berkenkamp, J., Skaar,K. \&VanSlooten, E. M. 2015. Using regionally grown grains and pulses in school meals, best practices, supply chain analysis and case studies. The institute for agriculture and trade policy works locally and globally at the intersection of policy and practice to ensure fair and sustainable food, farm and trade systems. www. iatp.org.

Fast, R. B. 1990. Breakfast cereals and how they are made In :Manufacturing Technology of Ready-To-Eat Cereals (Fast, R. B. and Caldwell, E. F., Eds). American Association of Cereal Chemists, Inc., St Paul, Minnesota, USA, pp. 15-42.

Galani, J. H. Y., Patel, N. J. \& Talati, J. G. 2017. Acry lamide - forming potential of cereals, legumes and roots and tubers analyzed by UPLC-UV. Food and Chemistry Toxicology, 108: 244248.

Gupta, C. \& Sehgal, S. 1991. Development, acceptability and nutritional value of weaning mixtures. Plant Foods for Human Nutrition, 41:107-116.

Jain, a. k., Kumar, S. \& Panwar, J. D.S. 2009. Antinutritional factors and their detoxification in pulses- a review. Agricultural Review, 30: 64-70.

Kanu, J. K.., Sandy, E.H.\&Kandeh, B.A.J. 2009. Production and evaluation of breakfast cereal-based porridge mixed with sesame and pigeon Peas for Adults. Pakistan Journal of Nutrition, 8 : 1335-1343.

Kapei, R., Pettini, L., Lonostro, A. \&Pesavento, G. 2015. Occurrence of acrylamide in breakfast cereals and biscuits available in Italy. Journal of Preventive Medicine and Hygiene, 56: E190-E195.

Kent, N. L. 1983. Technology of Cereals, Pergamon Press, Oxford, pp. 139 - 142.

Lin,Y. H \& Chen, H.J.1989. Relationship between trypsin inhibitor activity and water soluble protein and cumulative rainfall in sweet potatoes. Journal of the American Society for Horticultural Scince, 114: 418-818.
McKevith, B. 2004. Nutritional Aspects of Cereals Final Report to the Home Grown Cereal Authority, Nutrition Scientist, British Nutrition Foundation.

Meilgaard, M.,Cille, G. V. \& Cam, B. T. 1991. Sensory Evaluation Techniques, $2^{\text {nd }}$ ed. CRC Press Inc., Boca Raton, Florida, pp $22-45$.

Moreno, P. \&Salvado, V. 2000. Determination of eight water- and fat-soluble vitamins in multivitamin pharmaceutical formulations by high-performance liquid chromatography. Journal of Chromatography, A 870: 207-215.

Niva, M. 2007. All foods affect health, understanding of functional foods and healthy eating health-oriented and inns. Appetite, 48:384393.

Ojo, M. A., Ade-Omowaye, B. I. O. \&Ngoddy, P. O. 2014. Nutrients and phytochemical profiles of some selected underutilized hardto- cook legumes in Nigeria. International Journal of Food Science and Technology,2: 108-114.

Okafor, G. I. \& Usman, O.G. 2013. Production and evaluation of breakfast cereal from blends of Africa yam bean, maize, and deffated coconut. Journal of Food Processing and Preservation, 38:1037-1043.

Olorode Omobolanu, O. Idowle Michael, A., Bamgbose Adefunke \& Ayano Adeola, E. 2014. Chemical, Phytochemical and functional properties of selected seeds flours. International Journal of Nutrition and Food Science, 3:572-578.

Onwuka, G. I. 2005. Food Analysis and Instrumentation (theory and practice).Naphtali Prints , Nigeria. pp. 95 - 96.

Onyango, C. A., Ochanda,S. O., Mwasaru, M. A. , Ochieng, J. K. \&Mathooko, F. M. 2012. Development of instant breakfast cereals from optimized flours of pearl millet, red and white sorghum. Journal of Applied Bioscience, 51:3559-3566.

Prakash, V.H.P.\& Prakash,J.1999. In vitro protein digestibility of legumes cooked with spices. Nahrung,43: 19-21.

Samuel, F. O. \&Otegbayo, B. O. 2006. Chemical analysis and sensory evaluation of enriched with soybean and crayfish.. Nutrition and Food Science, 36:214-217. 
Steel, R. G. \&Torrie, J. H. 1980. Principle and procedures of statistics 2nd ed. McGraw Hill, New York, U.S.A.

Usman, G. O. 2012. Production and evaluation of breakfast cereals from blends of African yam bean (Sphenostylis stenocarpa),maize (Zea mays) and defatted coconut (Coco snucifera). Department of Food Science and Technology university of Nigeria, Nsukka,PG/M. Sc./09 /50997.

Usman, G.o. ,Ameh, U. E., Alifa, O. N. \& Babatunde, R. M. 2015. Proximate composition and anti-nutrient properties of breakfast cereal made from blends of local rice, soybeans and defatted coconut flours. Journal of Nutrition and Food Science, S11:006. doi: 10.4172/2155-9600.1000.

Wakil, S. M. \&Kazeem, M.O. 2012. Quality assessment of weaning food produced from fermented cereal-legume blends using starters.
International Journal of Food Research, 19: 1679-1685.

Wheeler, E. L. \&Ferrel, R. E. 1971. A method of phytic acid determination in wheat. Cereal Chemistry, 48: 312-316.

Woods, J. \& Walker, K. 2007.Choosing breakfast: How well does packet information on Australian breakfast cereals, bars and drinks reflect recommendations? Nutrition \& Dietetics, 64: 226-233.

Zambrano, F., Despinoy, P., Ormenese,R. C. S. C. $\&$ Faria, E. V. 2004. The use of guar and xanthan gums in the production of "light" low fat cakes. International Journal of Food Science and Technology, 39: 959-966.

Zhai, F-H., Wang,Q. \& Han, J-R. 2015. Nutritional components and antioxidants properties of seven kinds of cereals fermented by the basidiomycetes Agaricusblazei. Journal of Cereal Science, 65: 202-208. 


\section{توليف وتقويم بعض خلطات الإفطار الجليلده المننعه من الجبوب و البقوليات}

رحاب عبد السلا م مصطفي'، عزة السعيد محمد عبد الحليه' ، سلوى سلامة جبل' (1) معهد بحوث تكنولوجيا الأغذية - مركزالبحوث الزراعية ،الجيزة - مصر (r) قسم علوم وتقنية الأغذية - كلية الزراعة - الشاطبي - جامعة الإسكندرية 10\&0 ا الإسكندرية - مصر

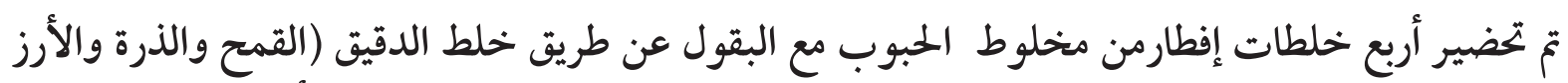

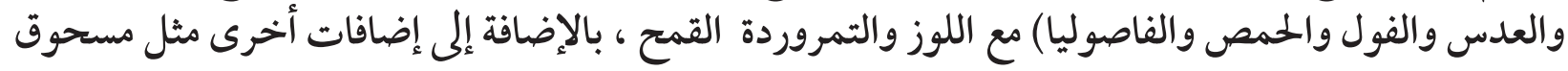

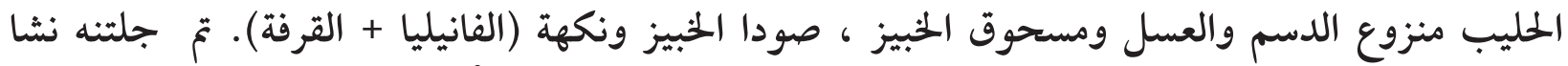

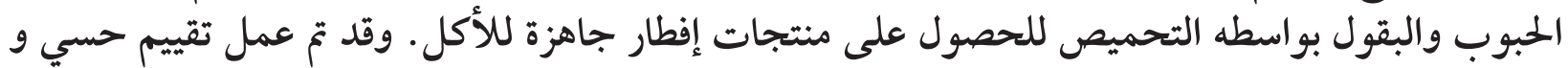

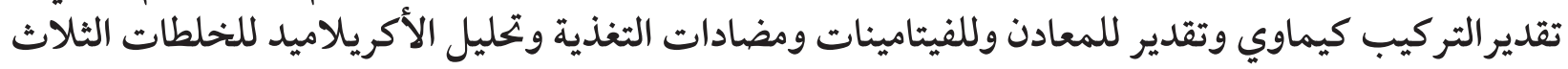

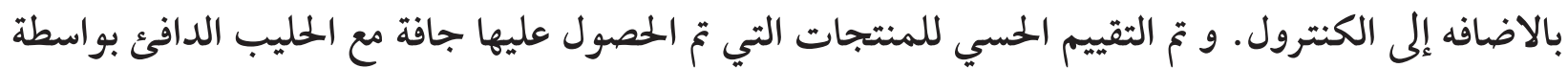

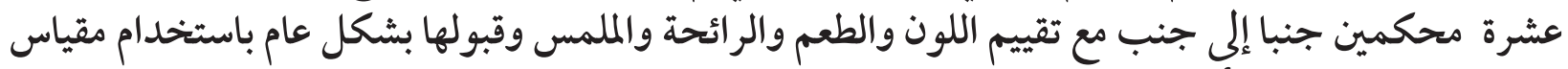

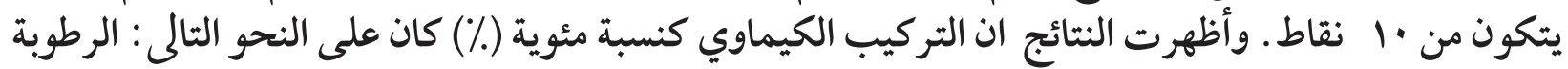

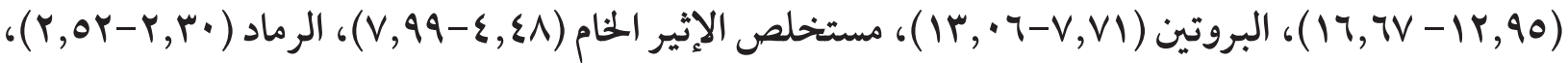

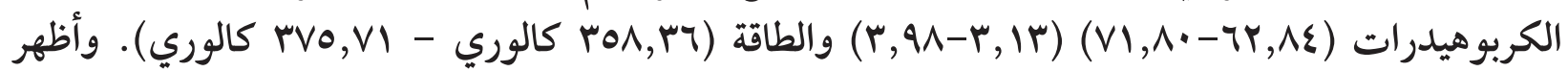

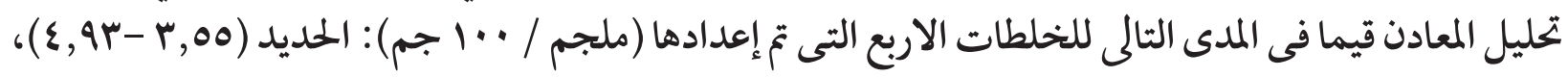

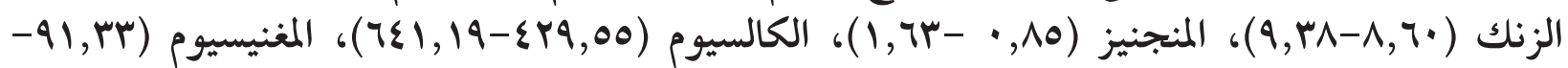

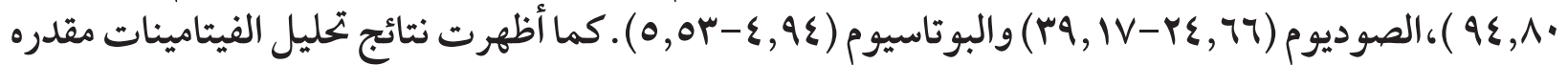

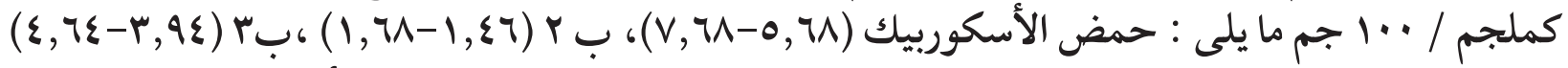



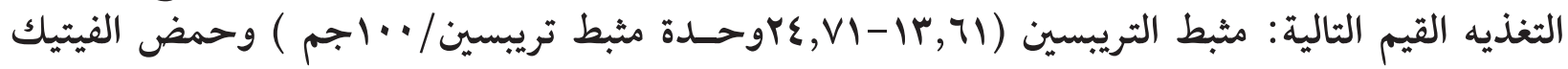

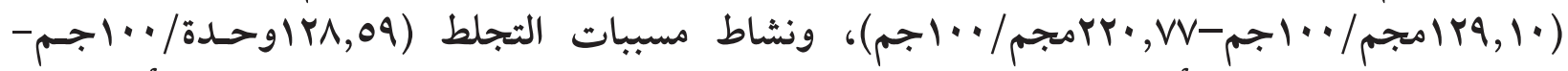

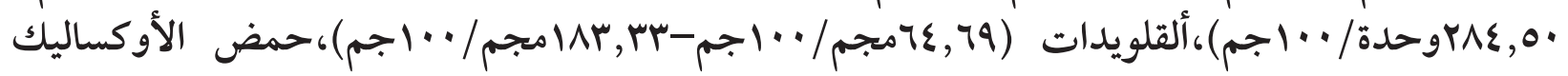
(9,VV)

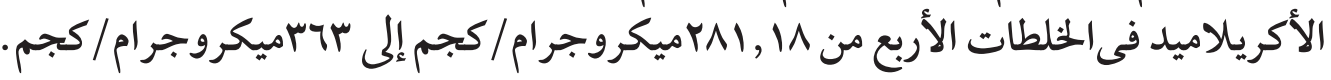

